\title{
EVALUASI IMPLEMENTASI KURIKULUM MUATAN LOKAL BAHASA DAERAH DAN PENDIDIKAN LINGKUNGAN HIDUP
}

\author{
Vidy Binsar Ferdianto dan Rusman \\ Universitas Pendidikan Indonesia \\ e-mail: vidy@student.upi.edu
}

\begin{abstract}
Abstrak
Penelitian ini bertujuan untuk mendeskripsikan tentang tingkat efektifitas pelaksanaan muatan lokal dari aspek konteks, masukan, proses, dan produk. Penelitian ini termasuk ke dalam penelitian evaluasi yang menunjukan prosedur dan proses pelaksanaan kurikulum muatan lokal pada tingkat SMA. Penelitian ini menganalisis efektifitas masing-masing komponen dari model evaluasi CIPP (Context, Input, Process, dan Product). Studi dilakukan kepada 30 orang guru muatan lokal dan 170 peserta didik dari kelas X dan XI. Data dikumpulkan dengan menggunakan kuesioner sebagai instrumen utama. Efektifitas pelaksanaan muatan lokal dilakukan dengan merubah skor mentah yang didapat dari kuesioner menjadi T-skor. Skor tersebut kemudian dianalisis menggunakan model Glickman. Hasil penelitian menunjukan secara umum pelaksanaan muatan lokal untuk Bahasa Daerah dan pendidikan lingkungan hidup sudah berjalan dengan baik, namun terdapat beberapa hal yang perlu ditingkatkan terutama dari aspek input dan process. Khusus untuk pendidikan lingkungan hidup diperlukan kebijakan baru dan sosialisasi dari pemerintah daerah agar penyelenggaraan pendidikan lingkungan hidup dapat lebih baik.
\end{abstract}

Kata Kunci: Bahasa Daerah, evaluasi kurikulum, implementasi kurikulum, muatan lokal, Pendidikan Lingkungan Hidup

\section{EVALUATION THE IMPLEMENTATION OF LOCAL CONTENT CURRICULUM OF LOCAL LANGUANGE AND ENVIROMENTAL EDUCATION}

\begin{abstract}
This study aimed to describe the level of effectiveness of the implementation of the local content of the aspects of context, input, process, and product. This study included in the evaluation study that shows procedures and processes local curriculum at the high school level. This study analyzes the effectiveness of each component of the evaluation model CIPP (Context, Input, Process, and Product). The study was conducted for 30 teachers of local content and 170 students from class X and XI. Data were collected using questionnaires as the main instrument. The effectiveness of the implementation of the local content achieved by converting raw scores obtained from the questionnaire into a T-score. The score was then analyzed using a model Glickman. The results showed the general implementation of local content for local language and environmental education has been going well, but there are some things that need to be improved, especially from the aspect of input and process. Especially for environmental education needed socialization and new policies from local governments to the implementation of environmental education can be better.
\end{abstract}

Keywords: curriculum evaluation, curriculum implementation, environmental education, Local Content, Local Language

\section{PENDAHULUAN}

Indonesia memiliki kekayaan yang sangat besar apabila dilihat dari segi demografis dan budaya. Kondisi demo- grafis Indonesia yang sangat beragam menyimpan potensi dan apabila dimanfaatkan dengan baik, maka Indonesia dapat menjadi negara yang disegani baik pada 
tingkat asia maupun dunia. Keragaman budaya di Indonesia, menjadi kekayaan yang hendaknya selalu terjaga dan dapat dilestarikan. Untuk dapat memaksimalkan potensi yang dimiliki dan melestarikan keragaman budaya di Indonesia, diperlukan sumber daya manusia yang berkualitas. Salah satu cara untuk memperoleh sumber daya manusia yang berkualitas adalah melalui pendidikan.

Pendidikan merupakan bagian yang integral dalam pembangunan nasional di Indonesia khususnya dalam peningkatan kualitas sumber daya manusia. Hal tersebut diamanatkan dalam Undang-Undang Nomor 20 Tahun 2003 tentang Sistem Pendidikan Nasional Pasal 3 yang menyatakan bahwa

"Pendidikan nasional berfungsi mengembangkan kemampuan, membentuk watak serta peradaban bangsa yang bermartabat dalam rangka mencerdaskan kehidupan bangsa, bertujuan untuk mengembangkan potensi peserta didik agar menjadi manusia yang beriman, bertaqwa kepada Tuhan Yang Maha Esa, berakhlak mulua, sehat, berilmu, cakap, kreatif, mandiri dan menjadi warga negara yang demokratis serta bertanggung jawab".

Pendidikan di Indonesia tidak terlepas dari kurikulum. Sejarah kurikulum mencatatkan bahwa sejak tahun 1994, pemerintah telah melaksanakan desentralisasi pendidikan. Pemerintah mengeluarkan kebijakan mengenai kurikulum muatan lokal yang mengharuskan sekolah untuk mengalokasikan $20 \%$ waktu dalam proses pembelajaran disusun berdasarkan kondisi lokal di sekolah. Program ini dirancang untuk mendukung desentralisasi pendidikan yang dijalankan oleh pemerintah. (Bjork, 2004; Yeom, Acedo, \& Utomo, 2002). Tiga tujuan yang hendak dicapai melalui Kurikulum Muatan Lokal adalah sekolah diharapkan dapat mendesain dan mengimplementasikan kurikulum yang dikembangkan sendiri oleh sekolah. Kedua, kurikulum yang dikembangkan diharapkan memiliki keterikatan yang erat dengan kondisi lokal yang terjadi di sekitar sekolah.
Ketiga, diharapkan melalui program ini diharapkan tingkat putus sekolah dapat menurun (Bjork, 2004). Melalui kebijakan tersebut perhatian pemerintah terhadap keunikan dan karakteristik masyarakat dan lingkungan di sekitar sekolah mulai meningkat. Di dalam perkembangan kurikulum di Indonesia, pemerintah secara konsisten mengeluarkan kebijakan-kebijakan terkait kurikulum yang mendukung desentralisasi pendidikan dengan penekanan terhadap karakteristik dan kondisi yang dimiliki masing-masing sekolah.

Saat ini dasar dalam kebijakan desentralisasi pendidikan di Indonesia adalah Undang-Undang Republik Indonesia Nomor 20 Tahun 2003 tentang Sistem Pendidikan Nasional pasal 36 ayat 2 menyatakan bahwa semua jenjang dan jenis pendidikan dikembangkan berdasarkan prinsip diversifikasi sesuai dengan satuan pendidikan, potensi daerah, dan peserta didik. Diversifikasi dalam konteks kurikulum berarti penganekaragaman/ pembedaan kurikulum di setiap daerah tetapi koridornya tetap mengacu pada kurikulum standar nasional. (Sutjipto, 2015). Berdasarkan pendapat tersebut, diversifikasi kurikulum merupakan komponen kurikulum yang terdiri dari tujuan, materi, metode dan evaluasi berdasarkan kondisi atau karakteristik daerah, sekolah dan peserta didik guna memberikan pengetahuan, keterampilan dan sikap yang dibutuhkan peserta didik. Salah satu bentuk diversifikasi kurikulum adalah hadirnya muatan lokal sebagai bagian dari kurikulum.

Muatan lokal sebagai komponen dalam kurikulum memiliki fungsi yakni fungsi penyesuaian, fungsi integrasi, dan fungsi perbedaan (Idi, 2014). Muatan lokal berfungsi untuk menyesuaikan kurikulum yang dikembangkan di sekolah dengan lingkungan dan kebutuhan daerah dan masyarakat. Oleh sebab itu komponen dalam kurikulum muatan lokal yakni tujuan, materi, metode, dan evaluasi hendaknya selaras dengan kondisi di sekitar sekolah. 
Fungsi kedua dari muatan lokal menjadikan kurikulum sebagai bagian yang integral dari masyarakat. Menjadi bagian yang integral dari masyarakat berarti kurikulum hendaknya berkontribusi dalam menghasilkan sumber daya manusia yang berguna bagi masyarakat dan juga dapat menjalankan tugas dan tanggung jawab sebagai bagian dari masyarakat.

Fungsi ketiga muatan lokal adalah memberikan ruang bagi setiap perbedaan yang ada. Perbedaan yang dimaksud adalah perbedaan minat dan bakat dari peserta didik dan juga keunikan dan potensi dari masing-masing daerah. Muatan lokal memberikan kesempatan bagi peserta didik untuk mengembangkan minat dan bakatnya sesuai dengan keuinikan dan potensi yang dimiliki oleh masing-masing daerah.

Di dalam Kurikulum 2013 yang berlaku di Indonesia saat ini, ketentuan mengenai muatan lokal diatur dalam Permendikbud Nomor 79 Tahun 2014 tentang Muatan Lokal Kurikulum 2013. Permendikbud tersebut mengatur mengenai tujuan, prinsip pengembangan, mekanisme usulan muatan lokal, hingga syarat yang dibutuhkan oleh satuan pendidikan dalam menyelenggarakan muatan lokal. Salah satu syarat yang dibutuhkan bagi satuan pendidikan dalam menyelenggarakan muatan lokal adalah tersedianya kebijakan yang dikeluarkan pemerintah daerah sesuai dengan wewenangnya masing-masing.

Salah satu daerah yang mengeluarkan kebijakan terkait pelaksanaan muatan lokal adalah Pemerintah Propinsi Jawa Barat. Terdapat dua kebijakan yang dikeluarkan yakni Peraturan Gubernur Jawa Barat Nomor 69 Tahun 2013 tentang Pembelajaran Muatan Lokal Bahasa dan Sastra Daerah Pada Jenjang Satuan Pendidikan Dasar dan Menengah dan Peraturan Gubernur Jawa Barat Nomor 25 tahun 2007 tentang Pedoman Pelaksanaan Kurikulum Muatan Lokal Pendidikan Lingkungan Hidup. Melalui dua kebijakan tersebut, semua satuan pendidikan yang berada di dalam wewenang Propinsi Jawa Barat dapat menjalankan muatan lokal bahasa daerah dan pendidikan lingkungan hidup. Satuan pendidikan yang berada di bawah pemerintah propinsi daerah adalah SMA dan SMK.

Muatan lokal bahasa daerah dan pendidikan lingkungan hidup menjadi hal yang penting untuk dipelajari peserta didik di sekolah. Bahasa telah menjadi salah satu isu penting dalam proses pembelajaran (Demmert Jr, 2011). Kegiatan berbahasa menjadi aktifitas yang harus dipelajari peserta didik agar menjamin peserta didik dapat menjalankan peran mereka dalam masyrakarat. Penerapan muatan lokal bahasa daerah di yang dilakukan oleh sekolah perlu dipertahankan untuk menjaga bahasa daerah agar tidak punah.

Pendidikan lingkungan hidup menjadi sesuatu yang penting untuk dipelajari peserta didik karena kesadaran untuk menjaga dan melestarikan lingkungan hidup sebaiknya ditanamkan sejak dini kepada peserta didik. Melalui proses pembelajaran di sekolah, peserta didik dapat mengetahui berbagai isu terkini mengenai pencemaran lingkungan, perkembangan teknologi lingkungan, hidup, solusi untuk mengatasi pencemaran lingkungan, dan berbagai hal yang diperlukan peserta didik untuk dapat menjaga dan melestarikan lingkungan hidup.

Muatan lokal bahasa daerah dan pendidikan lingkungan hidup menjadi dua muatan lokal yang sesuai dengan kondisi di Indonesia. Oleh karena itu, dalam rangka membentuk kualitas sumber daya manusia yang lebih baik salah satu hal yang harus diperhatikan adalah efektifitas implementtasi kurikulum muatan lokal bahasa daerah dan pendidikan lingkungan hidup yang dilakukan oleh sekolah.

Berdasarkan Peraturan Gubernur Jawa Barat Nomor 69 Tahun 2013 tentang Pembelajaran Muatan Lokal Bahasa salah satu bahasa daerah yang menjadi muatan lokal di Propinsi Jawa Barat adalah Bahasa Sunda. Tondo (2009) mengungkapkan bahwa berdasarkan data yang dikeluarkan oleh SIL, terdapat 27.000.000 penutur bahasa Sunda. Jumlah tersebut menyebabkan bahasa Sunda termasuk ke dalam bahasa daerah yang berstatus aman dari 
kepunahan. Walaupun berstatus aman, bahasa Sunda memiliki potensi untuk menjadi bahasa yang punah. Pramswari (2014) dalam penelitiannya menunjukan hasil yang kurang baik terkait penggunaan bahasa Sunda oleh peserta didik. Beberapa hal yang menyebabkan kondisi tersebut adalah intensitas penggunaan bahasa Sunda oleh peserta didik dalam kehidupan seharihari relatif rendah, anggapan bahwa bahasa Sunda merupakan mata pelajaran sulit. Penelitian yang dihasilkan oleh Pramswari juga menunjukan bahwa walaupun bahasa Sunda termasuk berstatus aman dari kepunahan, namun ancaman terhadap punahnya bahasa Sunda mulai terlihat. Berdasarkan kondisi tersebut diperlukan adanya evaluasi terkait pelaksanaan muatan lokal bahasa daerah di sekolah.

Muatan lokal pendidikan lingkungan hidup memiliki kendala tersendiri di dalam pelaksanaannya. Sebuah studi pendahuluan dilakukan terhadap salah satu satuan pendidikan yang melaksanakan pendidikan lingkungan hidup. Temuan menunjukan beberapa hal yang dapat mengganggu jalannya pelaksanaan. Pertama adalah tidak sesuainya kualifikasi akademik yang dimiliki dengan mata pelajaran yang diampu. Kedua adalah kurangnya dukungan pemerintah daerah terkait pengembangan profesi guru muatan lokal pendidikan lingkungan hidup. Ketiga adalah ketidakjelasan kebijakan yang dikeluarkan pemerintah daerah mengingat komponen di dalam kebijakan tersebut masih mengacu kepada Kurikilum 2006 sedangkan kurikulum yang digunakan saat ini adalah Kurikulum 2013. Berdasarkan ketiga hal tersebut, diperlukan sebuah evaluasi untuk melihat implementasi kurikulum muatan lokal pendidikan lingkungan hidup.

Evaluasi implementasi kurikulum bahasa Sunda dan pendidikan lingkungan hidup dapat dilakukan dengan melihat faktor-faktor yang dapat menghambat implementasi kedua muatan lokal tersebut. Adam (2014) mengidentifikasi kurangnya kemampuan guru dan sarana prasarana yang dimiliki sekolah dapat menghambat implementasi kurikulum. Selain itu faktor lain yang dapat menghambat implementasi kurikulum adalah kurangnya keterlibatan seluruh elemen sekolah, struktur birokrasi yang masih belum optimal, dan ketiadaan pedoman yang jelas (Dhanarko, Purnaweni, \& Kismartini, 2016). Nasir (2013) mengatakan bahwa permasalahan implementasi kurikulum berawal dari perencanaan, pelaksanaan, hingga evaluasi. Melihat beberapa penelitian tersebut, diperlukan sebuah model evaluasi yang komprehensif untuk dapat melihat implementasi kurikulum muatan lokal bahasa sunda dan pendidikan lingkungan hidup secara menyeluruh.

Salah satu model evaluasi adalah model evaluasi CIPP yang merupakan akronim dari Context, Input, Proces, dan Product. Model evaluasi CIPP merupakan salah satu model yang komprehensif karena melalui keempat aspek tersebut evaluasi tidak hanya berfokus pada hasil akhir saja tetapi keseluruhan tahapan dalam implementasi kurikulum mulai dari rasional penyelenggaraan, komponen yang mendukung pelaksanaan kurikulum, proses kurikulum, hingga produk atau hasil dari kurikulum. Evaluasi konteks dilakukan untuk menilai kebutuhan, masalah, dan peluang lingkungan, tujuan dan referensi, dan menilai kebutuhan yang ditargetkan untuk menilai kurikulum. Evaluasi masukan digunakan untuk menilai pemanfaatan sumber daya yang dimiliki terkait penggunannya dalam implementasi kurikulum. Evaluasi proses digunakan untuk menilai setiap unsur yang terlibat saat pelaksanaan dengan demikian dapat mengidentifikasi atau memantau apa yang terjadi, mengapa terjadi, komponen mana yang tidak berfungsi, aspek apa yang kurang atau hambatan yang mncul dan cara mengatasinya. Evaluasi produk dilakukan untuk menilai capaian yang diraih (Stufflebeam, 2003).

Berdasarkan pemaparan tersebut, penelitian ini akan mengevaluasi efektifitas penyelenggaraan kurikulum muatan lokal bahasa sunda dan pendidikan lingkungan hidup dilihat dari aspek konteks, masukan, proses, dan produk. Aspek konteks meliputi 
rasional penyelenggaraan muatan lokal dan ketersediaan program sekolah yang dapat mendukung pelaksanaan muatan lokal. Aspek masukan meliputi variabel sumber daya manusia, sarana prasarana, dan dukungan pemerintah. Aspek proses meliputi pelaksanaan pembelajaran dan supervisi serta pengawasan dari sekolah. Aspek produk meliputi penerapan muatan lokal dalam kehidupan sehari-hari peserta didik. Variabel-variabel tersebut mengacu kepada teori dan kebijakan yang sudah dikembangkan baik oleh pemerintah pusat maupun pemerintah daerah. Evaluasi akan dilakukan pada satuan pendidikan yang menjadi wewenang dari Pemerintah Propinsi Jawa Barat yakni pada satuan pendidikan SMA. Lokasi penelitian dilakukan di Kota Bandung sebagai bagian dari Propinsi Jawa Barat.

\section{METODE}

Penelitian yang dilakukan termasuk ke dalam penelitian evaluasi. Model evaluasi yang digunakan adalah model CIPP yang meliputi aspek konteks, masukan, proses dan produk. Hasan (2009) mengklasifikasikan model CIPP sebagai model evaluasi kuantitatif dengan paradigma positivistik. Metode yang digunakan adalah kuantitatif non experiment. Melalui metode ini, peneliti peneliti hanya merekam keadaan yang telah ada atau sedang terjadi dan tidak memunculkan data baru dengan sengaja (Arikunto, 2012). Berdasarkan metode ini, peneliti tidak mengadakan tes tersendiri untuk mengukur pencapaian peserta didik, melainkan menggunakan nilai tes yang telah dimiliki oleh peserta didik. Pemilihan metode non experiment sejalan dengan apa yang dinyatakan Hasan (2009) bahwa evaluasi harus berkaitan dengan kegiatan kurikulum yang terjadi di dalam kenyataan.

Populasi dalam penelitian ini adalah SMA yang berada di Kota Bandung. Metode sampling yang digunakan dalam penelitian ini adalah purposive sampling dan stratified random sampling. Melalui metode purposive sampling, sampel yang akan digunakan dalam penelitian ini adalah
SMA Negeri. Selanjutnya melalui stratified random sampling, SMA Negeri yang berada di Kota Bandung dibagi per kecamatan. Hasil dari stratified random sampling adalah 17 sekolah yang tersebar di 17 kecamatan di Kota Bandung yang memiliki SMA Negeri. Responden dalam penelitian ini adalah guru muatan lokal bahasa sunda dan pendidikan lingkungan hidup serta peserta didik di kelas X dan XI. Jumlah responden dalam penelitian ini adalah 30 orang guru muatan lokal dan 170 peserta didik yang terdiri dari 10 orang dari kelas X dan XI di masing-masing satuan pendidikan.

Instrumen penelitian yang digunakan dalam penelitian ini adalah kuesioner. Kuesioner digunakan untuk mengumpulkan data terkait sikap dan respon dari responden terhadap pernyataan dari aspek konteks, masukan, proses, dan produk. Skala yang digunakan dalam kuesioner adalah skala likert dengan 4 opsi. Kuesioner dibagi menjadi dua yakni kuesioner guru dan kuesioner peserta didik. pada kuesioner guru, aspek yang akan dievaluasi adalah aspek konteks, masukan, proses, dan produk. Sedangkan pada kuesioner peserta didik, aspek yang akan dievaluasi adalah aspek proses dan produk. Sebelum digunakan, instrumen melalui tahapan pengujian terlebih dahulu untuk mengetahui validitas dan reliabilitas instrumen.

Data hasil penelitian yang diperoleh dientry dan diolah terlebih dahulu. Pengolahan data dilakukan dengan melakukan tabulasi terkait jawaban responden atas variabel penelitian. Berikutnya skor mentah yang diperoleh dari tabulasi dikonversi menjadi z-score selanjutnya diubah lagi ke dalam Skor T (Arikunto, 2012). Setelah mendapatkan hasil dalam Skor T, data diproses secara deskriptif yang dibantu dengan analisis SPSS, selanjutnya hasil tersebut dianalisis melalui kuadran model Glickman untuk menentukan baik tidaknya suatu program yang diteliti (Dewi , Manuaba, \& Made Putra, 2015; Riptiani, Manuaba, \& Made Putra, 2015; Sriadnyani, Manuaba, \& Putra, 2015). 
Kualitas skor masing-masing variabel dihitung dengan meggunakan katagori T-skor. Jika $\mathrm{T} \geq 50$ adalah positif atau tinggi (+) dan $\mathrm{T}<50$ adalah negatif atau rendah (). Untuk mengetahui hasil akhir masingmasing variabel konteks, input, proses dan produk, dihitung dengan menjumlahkan skor positif (+) dan skor negatif (-). Jika jumlah skor positifnya lebih banyak atau sama dengan jumlah skor negatifnya berarti hasilnya positif $\left(\sum\right.$ Skor $+\geq \sum$ Skor $\left.-=+\right)$, begitu sebaliknya jika jumlah skor positifnya lebih kecil daripada jumlah skor negatifnya maka hasilnya negatif $\left(\sum\right.$ Skor + $<\sum$ Skor - = -).

Analisis kuadran yang digunakan dapat menggambarkan beberapa kedudukan keefektivan pelaksanaan kurikulum. Analisis dilakukan dengan melihat pola nilai positif atau negatif yang diperoleh dari keempat aspek. Berikut ini adalah diagram Glickman yang digunakan dalam penelitian ini.

\begin{tabular}{|c|c|}
\hline $\begin{array}{l}\text { Kuadran II } \\
\text { C I P P } \\
++++ \\
++-+ \\
+-++ \\
-+++ \\
\text { (Cukup Efektif) }\end{array}$ & $\begin{array}{c}\text { Kuadran I } \\
\text { C I P P } \\
++++ \\
++++ \\
++++ \\
++++ \\
\text { (Sangat Efektif) }\end{array}$ \\
\hline 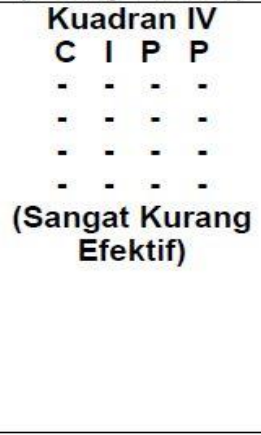 & 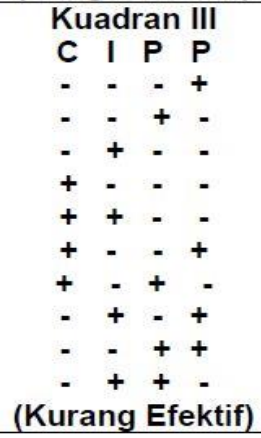 \\
\hline
\end{tabular}

Gambar 1. Diagram Glickman

(Dewi, Manuaba, \& Made Putra, 2015)

Kuadran I merupakan kategori sangat efektif. Kategori ini dapat diperoleh apabila semua komponen dalam konteks, masukan, proses, dan produk memperoleh hasil positif. Kuadran II merupakan kategori cukup efektif. Kategori ini dapat diperoleh apabila terdapat tiga komponen yang bernilai positif dan hanya satu komponen yang bernilai negatif. Kuadran III merupakan kategori kurang efektif. Kategori ini dapat diperoleh apabila terdapat dua komponen yang bernilai positif dan dua komponen bernilai negatif atau satu komponen yang bernilai positif dan tiga komponen yang bernilai negatif. Kuadran IV merupakan kategori sangat kurang efektif. Kategori dapat diperoleh apabila semua komponen memiliki hasil yang negatif.

\section{HASIL DAN PEMBAHASAN Hasil}

Studi evaluasi dilakukan di Kota Bandung, Jawa Barat yang melibatkan 17 SMA Negeri yang mewakili 17 kecamatan yang memiliki SMA Negeri. Dengan total responden sebanyak 30 guru muatan lokal dan 170 peserta didik pada kelas X dan XI.

Data penelitian diperoleh dari jawaban kuesioner guru dan peserta didik. Kuesioner guru terdiri atas 12 butir pernyataan pada aspek konteks, 16 butir pernyataan pada aspek masukan, 15 butir pernyataan pada aspek proses, dan 1 butir pernyataan pada aspek produk. Kuesioner peserta didik terdiri dari 16 butir pernyataan pada aspek proses dan 7 butir pernyataan pada aspek produk. Total butir pernyataan untuk guru adalah 43 butir pernyataan dan 23 butir pernyataan untuk peserta didik.

Berikut ini adalah hasil yang diperoleh terkait gambaran umum pelaksanaan muatan lokal bahasa Sunda dan pendidikan lingkungan hidup. Berdasarkan data yang diperoleh, seluruh sekolah yang dijadikan sampel dalam penelitian melaksanakan muatan lokal bahasa Sunda. Hanya terdapat 3 sekolah yang melaksanakan muatan lokal pendidikan lingkungan hidup selain muatan lokal bahasa Sunda. Seluruh responden menyatakan bahwa pemilihan muatan lokal bahasa Sunda didasarkan pada kebijakan Pemerintah Propinsi Jawa Barat melalui Peraturan Gubernur Nomor Jawa Barat Nomor 69 Tahun 2013 tentang Pembelajaran Muatan Lokal Bahasa dan Sastra Daerah Pada Jenjang Satuan Pendidikan Dasar dan Menengah. Bagi sekolah penyelenggara muatan pendidikan lingkungan hidup, selain berdasarkan kebijakan yang dikeluarkan oleh pemerintah propinsi 
melalui Peraturan Gubernur Jawa Barat Nomor 25 tahun 2007 tentang Pedoman Pelaksanaan Kurikulum Muatan Lokal Pendidikan Lingkungan Hidup, penentuan muatan lokal pendidikan lingkungan hidup didasarkan pada kebutuhan peserta didik dan lingkungan sekolah serta kesesuaian muatan lokal dengan visi dan misi sekolah.

Kondisi sumber daya manusia yang dimiliki oleh sekolah dilihat berdasarkan jenjang pendidikan, lama mengajar, dan kesesuaian akademik guru muatan lokal dengan muatan lokal yang diajarkan. Berikut ini adalah data mengenai kondisi sumber daya manusia di sekolah.

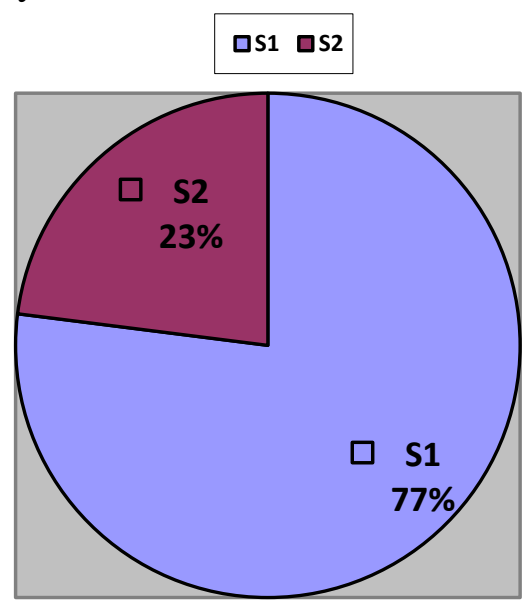

Gambar 2. Jenjang Pendidikan Guru

Data penelitian menunjukan bahwa $77 \%$ responden memiliki jenjang pendidikan Strata 1 dan 33\% responden memiliki jenjang pendidikan Strata 2. Hal ini berarti mayoritas responden memegang jenjang pendidikan Strata 1.

Tabel 1. Pengalaman Mengajar Guru Muatan Lokal

\begin{tabular}{lc}
\hline $\begin{array}{c}\text { Kategori Lama } \\
\text { Mengajar }\end{array}$ & Jumlah Guru \\
\hline $0-10$ Tahun & $66,67 \%$ \\
$11-20$ Tahun & $26,67 \%$ \\
$21-30$ Tahun & $0 \%$ \\
$31-40$ Tahun & $6,67 \%$ \\
\hline
\end{tabular}

Data penelitian menunjukan bahwa sebagian besar responden memiliki pengalaman mengajar mulai dari 0-10 tahun atau dapat dikatakan sebesar $66,67 \%$ dari jumlah responden. Sebanyak $26,67 \%$ memiliki pengalaman mengajar sebanyak 11-20 tahun dan $6,67 \%$ responden memiliki pengalaman mengajar sebanyak 31-40 tahun.

Sebanyak 95\% responden memiliki kualifikasi akademik yang sesuai dengan muatan lokal yang diajarkan. Di sisi lain, terdpat $5 \%$ dari total responden memiliki kualifikasi akademik yang tidak sesuai dengan muatan lokal yang diajarkan. Seluruh guru muatan lokal bahasa Sunda memiliki kualifikasi akademik yang linear sedangkan ditemukan 2 dari 3 orang guru pendidikan lingkungan hidup tidak memiliki kualifikasi akademik yang sesuai dengan muatan lokal yang diajarkan.

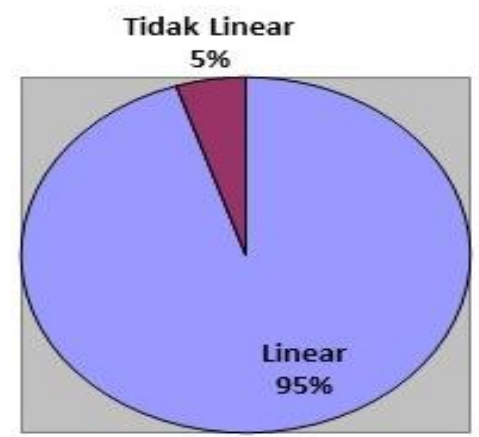

Gambar 3. Kualifikasi Akademik Guru

Terkait kondisi pengembangan kompetensi guru, sebanyak $60 \%$ responden menyatakan telah mengikuti pengembangan profesi baik yang diadakan oleh pemerintah daerah, MGMP, ataupun sekolah. Sedangkan, sisa responden sebanyak $40 \%$ menyatakan bahwa mereka belum mengikuti pengembangan profesi tersebut.

Berdasarkan gambaran umum yang diperoleh, hampir semua responden memiliki sumber daya yang dapat mendukung pelaksanaan muatan lokal di sekolah.

Data yang diperoleh dengan menggunakan kuesioner diolah untuk mendapatkan skor mentah. Skor mentah tersebut kemudian dikonversikan menjadi skor standar yang dapat digunakan untuk melihat efektifitas pelaksanaan muatan lokal dari aspek konteks, masukan, proses, dan produk. Berikut ini adalah hasil yang 
diperoleh melalui konversi skor mentah menjadi skor standar tersebut.

Tabel 2 Rekapitulasi perhitungan efektifitas variabel konteks, masukan, proses, dan produk

\begin{tabular}{lccc}
\hline \multicolumn{1}{c}{ Variabel } & $\mathrm{F}(+)$ & $\mathrm{F}(-)$ & Hasil \\
\hline Konteks & $76,47 \%$ & $23,53 \%$ & + \\
Masukan & $76,47 \%$ & $23,53 \%$ & + \\
Proses & $58,82 \%$ & $41,18 \%$ & + \\
Produk & $47,06 \%$ & $52,94 \%$ & - \\
\hline Hasil & & & Cukup \\
& & & Efektif \\
\hline
\end{tabular}

Hasil analisis Skor $\mathrm{T}$ menunjukan bahwa pada aspek konteks, frekuensi $\mathrm{T}$ positif adalah sebesar $76,47 \%$ dan frekuensi $\mathrm{T}$ negatif adalah sebesar $23,53 \%$. Terdapat selisih sebesar 52,94\% antara frekuensi $\mathrm{T}$ positif dan $\mathrm{T}$ negatif pada aspek konteks. Pada aspek masukan, frekuensi $\mathrm{T}$ positif adalah sebesar $76,47 \%$ dan frekuensi $\mathrm{T}$ negatif adalah sebesar $23,53 \%$. Terdapat selisih sebesar $52,94 \%$ antara frekuensi $\mathrm{T}$ positif dan $\mathrm{T}$ negatif pada aspek masukan. Pada aspek proses frekuensi $\mathrm{T}$ positif adalah sebesar 58,82\% dan frekuensi $\mathrm{T}$ negatif adalah sebesar 41,18\%. Terdapat selisih sebesar $17,65 \%$ antara frekuensi $\mathrm{T}$ positif dan $\mathrm{T}$ negatif pada aspek proses. Pada aspek produk frekuensi $\mathrm{T}$ positif adalah sebesar $47,06 \%$ dan frekuensi $\mathrm{T}$ negatif sebesar adalah 52,94\%. Terdapat selisih sebesar $5,88 \%$ antara frekuensi $\mathrm{T}$ positif dan $T$ negatif pada aspek produk.

Berdasarkan hasil perhitungan, hasil positif didapatkan oleh variabel konteks, masukan, dan proses. Sedangkan untuk hasil negatif diperoleh variabel produk. Pola yang diperoleh adalah Positif (+), Positif (+), Positif (+), Negatif (-). Hasil yang diperoleh menunjukan bahwa implementasi kurikulum muatan lokal bahasa daerah dan pendidikan lingkungan hidup ditinjau dari aspek konteks adalah efektif, segi masukan adalah efektif, segi proses adalah efektif, dan dari segi produk kurang efektif. Jika melihat kuadran Glickman, maka efektifitas implementasi kurikulum muatan lokal bahasa sunda dan pendidikan lingkungan hidup berada pada kuadran dua yakni cukup efektif.

\section{Pembahasan}

Efektifitas implementasi kurikulum muatan lokal bahasa daerah dan pendidikan lingkungan hidup adalah efektif apabila ditinjau dari aspek konteks. Efektifnya implementasi kurikulum muatan lokal bahasa daerah dan pendidikan lingkungan hidup tersebut disebabkan karena mendukungnya visi dan misi sekolah dengan muatan lokal yang dilaksanakan di sekolah, lingkungan sekolah dan sekitar yang mendukung pelaksanaan muatan lokal, dan sekolah telah memiliki program-program yang menunjang pelaksanaan muatan lokal. Selain itu, sekolah telah melakukan analisis terhadap kondisi dan karakteristik lingkungan dan masyarakat sekitar serta peserta didik.

Hasil evaluasi yang diperoleh pada aspek konteks sejalan dengan penelitian yang dilakukan oleh Sriadnyani, Manuaba, dan Putra (2015) yang menyatakan bahwa sekolah dengan visi dan misi, kondisi lingkungan dan peserta didik, serta kepemilikan programprogram yang menunjang pelaksanaan muatan lokal menunjukan hasil yang positif. Kesesuaian antara lingkungan sekolah dengan muatan lokal yang dilaksanakan di sekolah menjadi hal utama dalam konteks pelaksanaan muatan lokal. Hal tersebut disebabkan karena konsep dari muatan lokal adalah sebuah program pendidikan dalam bentuk mata pelajaran yang isi dan media penyampaiannya dikaitkan dengan lingkungan alam, sosial, dan budaya serta kebutuhan daerah yang wajib dipelajari oleh peserta didik (Idi, 2014).

Kesesuaian antara kebijakan pemerintah daerah dengan muatan lokal di sekolah juga turut mempengaruhi hasil positif yang diperoleh pada aspek konteks. Namun, khusus untuk muatan lokal pendidikan lingkungan hidup diperlukan kebijakan baru dari pemerintah daerah. Hal tersebut disebabkan karena kebijakan yang mengatur mengenai muatan lokal pendidikan lingkungan hidup masih mengikuti Kurikulum 2006, sedangkan kurikulum yang digunakan oleh pihak sekolah adalah Kurikulum 2013. Para guru muatan lokal pendidikan lingkungan hidup menyatakan bahwa 
pemerintah daerah perlu mengeluarkan revisi terkait Peraturan Gubernur Jawa Barat Nomor 25 tahun 2007 tentang Pedoman Pelaksanaan Kurikulum Muatan Lokal Pendidikan Lingkungan Hidup. Revisi tersebut dibutuhkan agar sekolah memiliki landasan hukum yang kuat untuk melaksanakan muatan lokal pendidikan lingkungan hidup. Selain itu dengan adanya revisi terkait pelaksanaan muatan lokal pendidikan lingkungan hidup, guru muatan lokal memiliki pedoman yang sesuai dengan Kurikulum 2013 dan dapat diterapkan dalam proses pembelajaran di kelas.

Efektifitas implementasi kurikulum muatan lokal bahasa daerah dan pendidikan lingkungan hidup adalah efektif apabila ditinjau dari aspek masukan. Efektifnya implementasi kurikulum muatan lokal bahasa daerah dan pendidikan lingkungan hidup tersebut disebabkan kondisi sumber daya manusia, dukungan pemerintah daerah, dan sarana prasarana yang dimiliki sekolah telah menunjang pelaksanaan muatan lokal di sekolah. Kualitas sumber daya manusia yang dimaksud disini adalah kualitas yang dimiliki guru. Guru yang profesional dapat dilihat berdasarkan jenjang pendidikan dan penguasaan guru terhadap materi ajar yang identik dengan kualifikasi akademi (Danim, 2002). Kesesuaian antara bidang ilmu yang ditempuh dengan bidang tugas dan jenjang pendidikan mempunyai pengaruh terhadap tingkat kompetensi mengajar guru (Widoyoko S. P., 2005). Berdasarkan data yang diperoleh seluruh guru telah memiliki jenjang pendidikan yang sesuai dengan Permendiknas tentang Standar Kualifikasi Akademik dan Kompetensi Guru yakni untuk menjadi guru SMA minimal memiliki jenjang pendidikan setara DIV atau S1. Akan tetapi terkait kesesuaian kualifikasi akademik dengan mata pelajaran yang diajarkan, untuk muatan lokal pendidikan lingkungan hidup masih memiliki kendala. Dari 3 orang responden yang berprofesi sebagai guru muatan lokal pendidikan lingkungan hidup, hanya 1 orang saja yang memiliki kualifikasi sesuai dengan mata pelajaran yang diajarkan. Sedangkan untuk muatan lokal bahasa Sunda, seluruh guru telah memiliki kualifikasi akademik yang sesuai dengan mata pelajaran yang diajar. Kondisi yang dialami oleh guru muatan lokal pendidikan lingkungan hidup, berpotensi untuk mengganggu implementasi kurikulum. Hal tersebut didasarkan pada hasil penelitian yang diungkapkan oleh Pakaya (2007) yakni ketidaksesuaian kualifikasi akademik yang dimiliki dengan tugas mengajar yang diberikan dapat mengakibatkan ketidakmampuan guru dalam mengajar.

Dukungan dari pemerintah daerah turut memberikan pengaruh terhadap implementasi sebuah kurikulum. Dukungan pemerintah berupa kebijakan dan komitmen dari pemerintah turut mempengaruhi keberhasilan implementasi kurikulum (Maryono, 2016). Dukungan dari pemerintah terkait sumber dan pengembangan profesional baik kepala sekolah maupun guru (Datnow \& Stringfield, 2000; Ringwalt, et al., 2003). Data penelitian menunjukan bahwa pemerintah daerah telah memberikan dukungan berupa kebijakan pemerintah daerah terkait pelaksanaan muatan lokal baik bahasa daerah maupun pendidikan lingkungan hidup. Selain itu, pemerintah telah melakukan sosialisasi terhadap guru-guru terkait pelaksanaan muatan lokal. Akan tetapi, pemerintah daerah perlu meningkatkan intensitas pelatihan yang diberikan kepada guru-guru. Sebanyak 45\% responden menyatakan bahwa pemerintah daerah jarang menyediakan pelatihan bagi guru muatan lokal. Pelatihan sebagai salah satu upaya dalam pengembangan profesional dibutuhkan untuk memberikan pengetahuan, keterampilan dan penanaman nilai kepada guru agar dapat digunakan ketika mengimplementasikan sebuah kurikulum serta karakteristik dari kurikulum yang akan diimplementasikan (Sorensen, $\mathrm{R} \mathrm{D}$; Goldsmith, L M; Mendez, Z Y; Maxwell, K T;, 2011; Rahayu, 2011). Selain itu, pengembangan profesional juga dibutuhkan agar guru memiliki kompetensi untuk pengembangan dan pengambilan keputusan dalam implementasi kurikulum.

Pemerintah daerah pun hendaknya meningkatkan bantuan yang diberikankepada guru-guru muatan lokal. Bantuan tersebut dapat berupa pemberian sertifikasi maupun 
status pegawai yang lebih baik. Data penelitian menunjukan bahwa sebagian besar guru merupakan non PNS yang belum tersertifikasi. Kondisi tersebut dapat mempengaruhi kualitas dari implementasi kurikulum muatan lokal. Murwanti (2013) dalam penelitiannya menunjukan bahwa status kepegawaian guru sangat mempengaruhi kinerja mengajar karena dengan adanya status yang dimiliki guru merasa mendapatkan pengakuan, penghargaan, dan memiliki rasa tanggung jawab terhadap hasil belajar peserta didik. Ketika guru menyatakan komitmennya untuk melaksanakan muatan lokal yang diwajibkan oleh pemerintah daerah, hendaknya pemerintah daerah turut memberikan komitmen berupa pemberian status pegawai dan sertifikasi agar guru dapat meningkatkan kompetensi yang dimiliki.

Selain kondisi sumber daya manusia dan dukungan pemerintah daerah, kondisi sarana dan prasarana yang dimiliki sekolah juga menunjang pelaksanaan muatan lokal. Data penelitian menunjukan bahwa sebagian besar sekolah responden telah memimiliki sarana dan prasarana yang menunjang. Sarana dan prasarana yang dimaksud disini adalah kepemilikan buku materi ajar dan berbagai peralatan yang dibutuhkan guru untuk menyampaikan materi muatan lokal di kelas.

Efektifitas implementasi kurikulum muatan lokal bahasa daerah dan pendidikan lingkungan hidup adalah efektif apabila ditinjau dari aspek proses. Efektifnya implementasi kurikulum muatan lokal bahasa daerah dan pendidikan lingkungan hidup tersebut disebabkan karena kesesuaian antara pelaksanaan pembelajaran dengan perencanaan yang telah dibuat oleh guru. Selain itu, peserta didik juga memberikan respon positif terhadap kegiatan pembelajaran yang dilakukan di dalam kelas. Respon positif yang diberikan oleh peserta didik berdasarkan pendapat sebagian besar responden peserta didik yang menyatakan bahwa metode pembelajaran yang digunakan oleh guru membuat peserta didik menjadi lebih termotivasi dan turut terlibat aktif di dalam proses pembelajaran. Hasil tersebut sejalan dengan penelitian yang dilakukan Hindun (2012) dengan hasil penelitian adalah variasi gaya mengajar guru berpengaruh terhadap motivasi belajar siswa yang secara langsung berdampak pada hasil belajar yang diperoleh.

Berdasarkan data penelitian, sebagian besar responden menyatakan setuju dengan penguasaan guru terhadap materi yang diajarkan. Selain itu, penggunaan beragam media oleh guru juga memberikan respon positif dari peserta didik. Kemampuan guru untuk mengaitkan materi dengan kondisi di sekitar sekolah turut memberikan dampak terhadap respon positif dari peserta didik. Melihat hasil tersebut, guru merupakan faktor utama dari keberhasilan implementasi kurikulum. Rusman (2011) menyatakan bahwa guru merupakan ujung tombak sehingga harus mampu untuk memahami esensi tujuan yang dicapai, penjabaran tujuan menjadi indikator yang lebih spesifik, menerjemahkan tujuan menjadi kegiatan pembelajaran, dan penentuan metode dan model pembelajaran yang akan digunakan. Fullan (dalam Orstein dan Hunkins, 2013) mengungkapkan hal yang senada yakni faktor yang mempengaruhi implementasi kurikulum adalah adalah pemahaman dari implementor terkait karakteristik perubahan yang akan dilakukan.Implementor yang dimaksudkan disini adalah guru. Jika guru memiliki pemahaman yang baik akan karakteristik materi yang diajarkan, maka implementasi kurikulum dapat berjalan dengan baik.

Hal lain yang mempengaruhi perolehan nilai positif pada aspek proses adalah tersedianya sarana dan prasarana sekolah yang menunjang serta dukungan pemerintah dalam bentuk kebijakan yang dikeluarkan pemerintah daerah terkait pelaksanaan muatan lokal. Selain itu kesiapan dan motivasi yang dimiliki peserta didik, serta sumber daya manusia yang dimiliki sekolah telah memenuhi kebutuhan dalam melaksanakan muatan lokal di sekolah. Hal ini sesuai dengan Permendikbud Nomor 79 Tahun 2014 tentang Muatan Lokal Kurikulum 2013 pasal 9 poin a dan $b$ yang menyatakan bahwa pelaksanaan muatan lokal di sekolah perlu didukung oleh kebijakan pemerintah sesuai dengan kewenangannya dan ketersediaan sumber daya pendidikan yang dibutuhkan untuk melaksanakan muatan lokal. 
Faktor lain yang mendukung efektifitas implementasi berdasarkan aspek proses adalah supervisi dan pengawasan yang dilakukan oleh sekolah. Data penelitian menunjukan bahwa sebagian responden menyatakan sekolah telah melakukan pemeriksanaan dokumen kurikulum, memberikan solusi terhadap kendala yang dialami guru dalam proses pebelajaran, dan melakukan evaluasi terhadap pembelajaran muatan lokal yang telah dilakukan oleh guru.

Efektifitas implementasi kurikulum muatan lokal bahasa daerah dan pendidikan lingkungan hidup adalah tidak efektif apabila ditinjau dari aspek produk. Hal tersebut disebabkan karena sebagian responden guru menyatakan bahwa peserta didik memahami materi muatan lokal yang disampaikan namun belum menerapkan materi yang diperoleh secara baik dan konsisten. Pencapaian akademik peserta didik sebaiknya diiringi dengan pemberian kesempatan bagi peserta didik untuk dapat menerapkan pengetahuan dan keterampilan yang diperoleh baik dalam kehidupan bermasyarakat maunpun dalam kehidupan sehari-hari. Pencapaian akademik sebaiknya tidak dijadikan satu-satunya hasil yang dicapai melalui proses implementasi kurikulum. Ansyar (2015) mengatakan bahwa implementasi berarti kurikulum yang berlaku dilaksanakan untuk melakukan perubahan agar siswa menguasai pengetahuan, keterampilan, nilai-nilai dan kompetensi agar dapat hidup di masyarakat. Wahyudin (2014) menjelaskan bahwa tujuan akhir dari proses implementasi kurikulum adalah terjadinya perubahan pada diri peserta didik yang meliputi pengetahuan, keterampilan, dan sikap. Lebih lanjut Rusman (2011) mengatakan bahwa "implementasi kurikulum seharusnya menempatkan pengembangan kreativitas siswa lebih dari penguasaan materi”. Berdasarkan ketiga pendapat tersebut, hendaknya perubahan yang dialami oleh peserta didik sebagai akibat dari implementasi kurikulum tidak hanya pada aspek pengetahuan saja, melainkan juga aspek kemampuan dan sikap. Ketiga komponen tersebut diperlukan peserta didik agar materi yang telah dipelajari di sekolah dapat dipraktekan di dalam kehidupan bermasyarakat.

Pembelajaran bahasa daerah memiliki tiga fungsi pokok yakni alat komunikasi, edukatif, dan kultural (Wibawa, 2013). Fungsi alat komunikasi diarahkan agar peserta didik dapat menggunakan bahasa daerah sebagai alat komunikasi baik kepada keluarga maupun masyarakat. Fungsi edukatif agar peserta didik dapat memahami nilai budaya daerah dan menjadikannya sebagai prinsip dalam menjalani kehidupan di masyarakat. Fungsi kultural agar nilai-nilai budaya daerah dapat dilestarikan dan dipelajari terus menerus. Melihat fungsi pembelajaran bahasa daerah yang sangat erat dengan masyarakat, sekolah hendaknya memiliki programprogram yang melibatkan masyarakat sekitar, sehingga peserta didik dapat berinteraksi dengan menggunakan bahasa Sunda yang telah dipelajari.

\section{PENUTUP}

Merujuk kepada permasalahan penelitian yang telah dirumuskan, tujuan penelitian yang telah ditetapkan, dan hasil analisis yang telah dipaparkan pada bagian sebelumnya, dirumuskan kesimpulan hasil penelitian sebagai berikut.

1. Efektifitas implementasi muatan lokal bahasa daerah dan pendidikan lingkungan hidup berdasarkan aspek konteks menunjukan hasil positif.

2. Efektifitas implementasi muatan lokal muatan lokal bahasa daerah dan pendidikan lingkungan hidup berdasarkan aspek masukan menunjukan hasil positif.

3. Efektifitas implementasi muatan lokal muatan lokal bahasa daerah dan pendidikan lingkungan hidup berdasarkan aspek proses menunjukan hasil positif.

4. Efektifitas implementasi muatan lokal muatan lokal bahasa daerah dan pendidikan lingkungan hidup berdasarkan aspek produk menunjukan hasil negatif.

5. Hasil yang positif pada aspek konteks dipengaruhi oleh rasional penyelenggaraan muatan lokal yang telah sesuai 
dengan ketentuan yang diatur dalam Permendikbud Nomor 79 Tahun 2014 tentang Muatan Lokal Kurikulum 2013 dan kebijakan yang telah dikeluarkan oleh Pemerintah Propinsi.

6. Hasil yang positif pada aspek masukan dipengaruhi oleh kondisi sumber daya manusia, dukungan pemerintah daerah, dan tersediannya sarana dan prasarana yang menunjang.

7. Hasil yang positif pada aspek proses dipengaruhi oleh kesesuaian antara pelaksanaan dengan rencana yang telah dibuat dan dilaksanakannya supervisi dan pengawasan yang ketat tekait dokumen kurikulum dan proses pembelajaran.

8. Hasil yang negatif pada aspek produk disebabkan kurangnya kesempatan bagi peserta didik untuk mengaplikasikan materi muatan lokal yang telah didapatkan.

Rekomendasi yang dapat diberikan kepada pemerintah daerah adalah memfasilitasi sekolah pelaksana muatan lokal pendidikan lingkungan hidup dengan kebijakan yang telah mengakomodir pelaksanaan Kurikulum 2013 di sekolah. Selain itu, pemerintah daerah diharapkan dapa terus meningkatkan pelatihanpelatihan yang dapat meningkatkan kompetensi guru agar pelaksanaan kurikulum muatan lokal yang sudah berjalan dengan baik dapat menjadi lebih baik lagi di kemudian hari.

Bagi satuan pendidikan, rekomendasi yang dapat disampaikan adalah terus menjaga dan meningkatkan kualitas pelaksanaan muatan lokal agar dapat senantiasa memberikan pelayanan yang maksimal bagi peserta didik.

\section{DAFTAR PUSTAKA}

Adam, A. B. (2014). Analisis implementasi kebijakan kurikulum berbasis lingkungan hidup pada program adiwiyata mandiri di SDN Dinoyo 2 Malang. Jurnal Kebijakan dan Pengembangan Pendidikan, 166-173.
Ansyar, M. (2015). Kurikulum hakikat, fondasi, desain dan pengembangan. Jakarta: Prenadamedia Group.

Arikunto, S. (2012). Dasar-dasar evaluasi pendidikan. Jakarta: Bumi Aksara.

Bjork, C. (2004). Decentralization in education in Indonesia. International Review of Education, 245 - 262.

Danim, S. (2002). Inovasi pendidikan dalam upaya peningkatan profesionalisme tenaga kependidikan. Bandung: Pustaka Setia.

Datnow, A., \& Stringfield, S. (2000). Working together for reliable school reform. Journal of Education for Students Placed at Risk (JESPAR), 183-204.

Demmert Jr, W. G. (2011). What is culturebased education? Understanding pedagogy and curriculum. Honoring our heritage: Culturally appropriate approaches to Indigenous education, 1-9.

Dewi , N. L., Manuaba, I. B., \& Made Putra, M. P. (2015). Studi evaluasi implementasi kurikulum 2013 ditinjau dari context, input, process dan product (cipp) pada sekolah dasar negeri di wilayah pinggiran kabupaten badung. Mimbar PGSD Undiksha, 1 - 11.

Dhanarko, T. B., Purnaweni, H., \& Kismartini, K. (2016). Implementasi kebijakan pendidikan lingkungan melalui program adiwiyata di propinsi jawa tengah (studi kasus sma negeri 2 pati dan sma negeri 9 semarang). Retrieved from http://eprints.undip.ac.id/55962/

Hasan, H. (2009). Evaluasi kurikulum. Bandung: Remaja Rosdakarya.

Hindun, L. (2012). Hubungan antara persepsi siswa mengenai variasi gaya mengajar guru dalam pembelajaran biologi dengan motivasi belajar siswa kelas $x$ di MAN Kendal. Semarang: IAIN Walisongo.

Idi, A. (2014). Pengembangan kurikulum teori dan praktik. Depok: PT Rajagrafindo Persada. 
Maryono. (2016). The implementation of schools' policy in the development of the local content curriculum in primary schools in pacitan, indonesia. Academic Journal Education Research and Review, 891-906.

Murwanti, S. (2013). Pengaruh sertifikasi profesi guru terhadap motivasi kerja dan kinerja guru di smk negeri sesurakarta. Jurnal Pendidikan Bisnis dan Ekonomi (BISE), 12-21.

Nasir, M. (2013). Pengembangan kurikulum muatan lokal dalam konteks pendidikan islam di madrasah. HUNAFA: Jurnal Studia Islamika, 1-18.

Orstein, A. C., \& Hunkins, F. P. (2013). Curriculum foundation, principles, and issues. New Jersey: Pearson.

Pakaya, Y. (2007). Relevansi antara keprofesional guru dengan tugas mengajar pada mata pelajaran sejarah (studi kasus di SMA negeri Gorontalo). Inovasi, 102-113.

Pramswari, L. P. (2014). Pembelajaran bahasa sunda di wilayah perbatasan: dilema implementasi kurikulum 2013. Mimbar Sekolah Dasar, 201208.

Rahayu, A. T. (2011). Pengaruh kualifikasi akademik pelatihan, pengalaman mengajar, dan persepsi guru tentang penerapan pembelajaran ips secara terpadu terhadap kinerja guru ips terpadu di smp negeri se-kota blitar. Malang: Fakultas Ekonomi Universitas Negeri Malang.

Ringwalt, C. L., Ennet, S., Johnson, R., Rohrbach, L. A., Simons, R. A., Vincus, A., \& Thorne, J. (2003). Factors associated with fidelity to substance use prevention curriculum guides in the nation's middle schools. Health Education \& Behavior, 375391.

Riptiani, K. M., Manuaba, I., \& Made Putra, M. P. (2015). Studi evaluasi implementasi kurikulum 2013 ditinjau dari cipp pada sekolah dasar negeri di wilayah perkotaan kabupaten badung. e-Journal PGSD Universitas Pendidikan Ganesha.

Rusman. (2011). Manajemen kurikulum. Jakarta: PT Rajagrafindo Persada.

Sorensen, R D; Goldsmith, L M; Mendez, Z Y; Maxwell, K T;. (2011). The principal $s$ guide to curriculum leadership. Corwin press. London: Corwin, Sage Ltd.

Sriadnyani, N. M., Manuaba, I. S., \& Putra, M. (2015). Studi evaluasi implementasi kurikulum 2013 ditinjau dari cipp pada sekolah dasar negeri di wilayah perkotaan kabupaten badung. E-Journal PGSD Universitas Pendidikan Ganesha.

Stufflebeam, D. L. (2003). The CIPP model for evaluation. The International Handbook of Educational Evaluation, 31 - 62.

Sutjipto, S. (2015). Diversifikasi kurikulum dalam kerangka desentralisasi pendidikan. Jurnal Pendidikan dan Kebudayaan, 317-338.

Tondo, F. H. (2009). Kepunahan bahasabahasa daerah: faktor penyebab dan implikasi etnolinguistis. Jurnal Masyarakat dan Budaya, 277 - 295.

Wahyudin, D. (2014). Manajemen kurikulum. Bandung: PT Remaja Rosdakarya Offset.

Wibawa, S. (2013). Mengukuhkan pembelajaran bahasa, sastra, dan budaya daerah sebagai muatan lokal. Konferensi Internasional Budaya Daerah III (pp. 1-13). Sukoharjo: Universitas Veteran.

Widoyoko, S. P. (2005). Kompetensi mengajar guru ips SMA kabupaten Purworejo. Ditjen Pendidikan Nasional, 1-14.

Yeom, M., Acedo, C., \& Utomo, E. (2002). The reform of secondary education in indonesia during the 1990s: basic education expansion and quality improvement through curriculum decentralization. Asia Pacific Education Review, 56-68. 